\title{
Tele-education applied to human communication health to cope with triple epidemics in the state of Pernambuco, Brazil: an experience report
}

Tatiana de Paula Santana da Silva ${ }^{1}$ https://orcid.org/0000-0002-1095-7784

Fabiana de Oliveira Silva Sousa ${ }^{2}$ https://orcid.org/0000-0002-4482-3151

Gabrielle Araújo Leite ${ }^{1}$ https://orcid.org/0000-0003-1372-0931

Maria Edvany de Melo Pereira ${ }^{3}$ https://orcid.org/0000-0002-1878-2149

Marilia Cleide Tenório Gomes ${ }^{3}$ https://orcid.org/0000-0002-9485-6824

Mirella Rodrigues ${ }^{3}$ https://orcid.org/0000-0001-5113-7144

Maria Luiza Lopes Timóteo de Lima ${ }^{3}$ https://orcid.org/0000-0001-8600-0017

Cynthia Maria Barboza do Nascimento ${ }^{3}$ https://orcid.org/0000-0001-9197-2136

Universidade Federal de Pernambuco UFPE, Recife, Pernambuco, Brasil. Centro de Pesquisas Aggeu Magalhães/ FIOCRUZ, Recife, Pernambuco, Brasil. Universidade Federal de Pernambuco UFPE, Departamento de Fonoaudiologia, Recife, Pernambuco, Brasil.

Research developed at Universidade Federal de Pernambuco, Recife, Pernambuco, Brazil.

Conflict of interests: Nonexistent

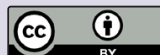

Received on: July 17, 2019 Accepted on: January 27, 2020

Corresponding address:

Tatiana de Paula Santana da Silva Estrada do Caenga $n^{0} 601$,

Águas Compridas

CEP: 53210-460 - Olinda, Pernambuco, Brasil

E-mail: Tatianapss2@gmail.com

\section{ABSTRACT}

Objective: to evaluate the implementation of tele-education sessions for health professionals working in primary care and at Family Health Support Centers, addressing the repercussions of triple endemics to human communication health in the state of Pernambuco, Brazil.

Methods: following approval from the ethics committee, an experience report was performed, in partnership with a telehealth center. The methods involved three steps: 1- creation of a flowchart for the implementation phases; 2- offer of educational sessions; 3- evaluation of satisfaction on the part of the public.

Results: the implementation process consisted of five phases: institutional partnership, training, planning, offering of service and evaluation. Seven educational sessions were held, with a total of 175 viewings. Regarding satisfaction, $100 \%$ of the participants considered the topics interesting and that the learning experience was important to their professional qualification. Most of them (86\%), reported feeling secure regarding the retention of the knowledge acquired.

Conclusion: the implementation of the tele-education service had repercussions on statewide views and was approved by $100 \%$ of the participants, constituting a promising, easily accessible, comprehensive proposal in the continued education of health professionals working in primary care and at Family Health Support Centers

Keywords: Speech, Language and Hearing Sciences; Telemedicine; Microcephaly; Education, Distance; Education, Continuing 


\section{INTRODUCTION}

Arboviruses are found in several continents and currently compose the triple epidemics of dengue, zika and chikungunya. These viruses constitute a serious public health problem due to the severe manifestations that can occur in affected individuals, especially in more vulnerable segments of the population, such as pregnant women, seniors and children 1 .

Zika virus in particular, has challenged the scientific community and health professionals in Brazil and especially in the state of Pernambuco ${ }^{1}$ due to the high number of cases. Between October 2015 and March 2019, 375 cases of microencephaly caused by Zika virus were diagnosed and confirmed in children. The state of alert is justified by the serious consequences resulting from congenital infection by Zika virus, especially microencephaly and other neurological anomalies that occur during embryonic and fetal development.

Knowledge on the repercussions of infection to the health of children with this condition is scarce and little is known regarding its impact on communication health ${ }^{2,3}$. Studies in the field of speech therapy reveal that children with microencephaly resulting from Zika virus present delays in the development of communication skills ${ }^{1}$ as well as the development of chewing and swallowing functions, with the common occurrence of symptoms of dysphagia.

Thus, there is an evident need to establish continuing education actions and strategies for health professionals who work in this context toward the resolution of the epidemics and the integral care of affected individuals ${ }^{4}$. Permanent health education is a learning strategy $y^{5-9}$ for which information technologies are fundamental to the promotion of discussions and the dissemination of the information necessary for knowledge building, especially in situations that require greater effort, such as combating an epidemics ${ }^{10-14}$.

Distance education initiatives, also known as telehealth practices, are organized by telehealth centers with the aim of offering services and solutions for health professionals that can contribute to their personal improvement and qualification ${ }^{15}$. Tele-education services offer a set of telehealth actions to assist in the continuing education of health professionals who work in primary care without having to go on leave from their daily activities ${ }^{16}$.

Different health professionals, including speech therapists, can use tele-education in the daily practice of their work. Legal assistance was instituted in 2013 by the Federal Speech Therapy Board through Resolution no $427^{17}$, which regulates telehealth actions in speech therapy. Health professionals in the field of human communication can use these resources in the context of primary care to improve their knowledge, ensuring access to alternative technologies that can improve the quality of life of individuals and communities ${ }^{18}$.

Therefore, the aim of the present study was to evaluate the implantation of tele-education sessions for health professionals who work in primary care and at Family Health Support Centers, addressing the repercussions of the triple endemics to human communication health.

\section{METHODS}

The present study is part of a research project that received approval from the Human Research Ethics Committee of Universidade Federal de Pernambuco (certificate number: 113359/2015). This is an experience report, the aim of which is to describe and/ or evaluate an action conducted at a location/service or for a specific group. The experience occurred between January 2016 and June 2018 in partnership with the Telehealth Center of the Federal University Hospital in the state of Pernambuco, Brazil.

To improve the reader's understanding of the implantation process, we present the methodological process in steps, as follows:

\section{Step 1 - Creation of a flowchart of the implantation}

phases: In this step, the authors designed the model in the form of a flowchart with the actions necessary for the offer of the tele-education service in human communication health related to coping with the triple epidemics. The details of each phase of the flowchart for the implantation process are presented below:

1. Institutional partnership: Meetings were held with the partner institutions for the presentation of the proposal, formalization of technical and operational accords and the definition of goals and deadlines for the realization of the project. Legal documents were produced and the agreement was formalized with the signing of these documents.

2. Training: Technical and operational meetings were held with all members of the team to construct the work plan for each member and train the individuals in the proper use of the technologies to be used in the web conferencing sessions.

3. Planning: Meetings were held to define the topics that would be addressed in the joint action with the 
participating conference members. The content of the topics was also defined and the presentation of each session was revised.

4. Offer of services: The process of offering services consisted of web conferencing sessions at pre-determined times and a survey of the satisfaction of the participating public.

5. Evaluation of action: The evaluation process consisted of the collection and analysis of data from the satisfaction survey to determine the scope, visibility and contributions of the joint action with the target public.

Step 2 - Creation and offer of educational sessions addressing the repercussion of the triple epidemics to human communication health: The authors presented an overview of all educational sessions (40-minute talks to explain the content). The educational sessions were produced and edited at the lab and video studio of the Telehealth Center. The materials were created and presented by health professionals and speech therapists who are specialists in the field. The completed sessions were made available in video format in a virtual learning environment for all health professionals registered with the Brazilian Telehealth Program created mainly for those working in primary care.

Step 3 - Evaluation of satisfaction on the part of the participating public: The authors summarized the opinions of the public regarding their satisfaction and the repercussions of the project. All health professionals who accessed the videos were asked to participate in the online satisfaction survey involving the use of a questionnaire with multiple choice questions divided into two sections: 1- Personal identification and professional profile (four items); 2- Degree of satisfaction (four items).

The content was presented in Power Point and the sessions were transmitted using a web conferencing tool with the aid of Adobe ${ }^{\circledR}$ Acrobat ${ }^{\circledR}$ Connect $^{\text {TM }}$ (ver sion 2.0) in real time with a maximum capacity of up to 99 points simultaneously connected per session. The sessions were informed through e-mails, using the mailing list of the Regional Speech Therapy Board and through the site of the Telehealth Center, containing information on the project, form of access and schedule of the sessions. All those who expressed interest signed a statement of informed consent and were included in the study.

Data analysis involved the creation and tabulation of a databank with the aid of the Statistical Package for the Social Sciences (SPSS, version 19.0). The results are displayed descriptively in tables.

\section{RESULTS}

Figure 1 displays the flowchart of the implantation of the tele-education service addressing human communication health related to the triple epidemics, with the identification of all phases described for Step 1 above. 


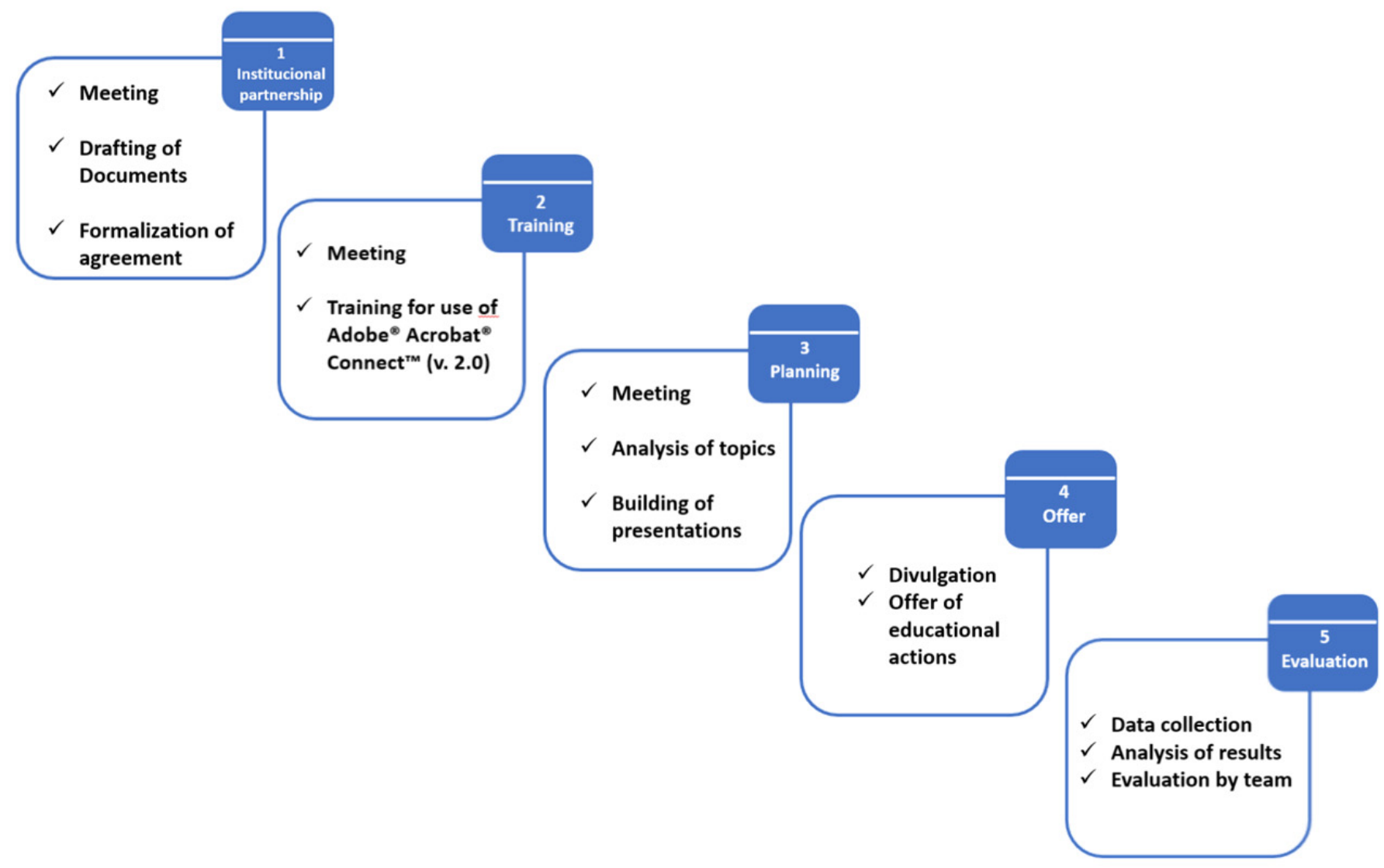

Source: Authors.

Figure 1. Flowchart of implantation of tele-education service addressing human communication health related to the triple epidemics

Figure 2 details all seven sessions produced throughout the experience related to Step 2 (creation and offer of educational sessions addressing the repercussions of the triple epidemics to human communication health). The actions were presented during monthly web conferencing sessions each lasting an average of 60 minutes. Access to the sessions was possible through electronic devices (laptops, desktops, tablets and smartphones) connected to the internet. All participants needed to be connected at the scheduled time at the health units or other spaces through access to the educational platform of the Telehealth Center. All viewings within the period of reference established for the data collection were quantified.
The distribution of the content was prioritized in an attempt to address the topics in the most comprehensive manner, including issues related to conceptualization, epidemiological aspects and the repercussions of infection to different aspects of the health of human communication. The first session, entitled "Current Panorama of the Triple Epidemics (Zika, Chikungunya and Dengue) in Brazil" was the most accessed (91 viewings), which demonstrates a greater interest on the part of the public regarding a more conceptual approach to arboviruses in comparison to specific actions related to minimizing the consequences stemming from infection. 


\begin{tabular}{|c|c|c|}
\hline Title of action & $\begin{array}{l}\text { Total number of } \\
\text { accesses }\end{array}$ & Accesses per municipality in state of Pernambuco \\
\hline $\begin{array}{l}\text { Current Panorama of the Triple Epidemics (Zika, } \\
\text { Chikungunya and Dengue) in Brazil }\end{array}$ & 91 & $\begin{array}{c}\checkmark \text { Jurema } \\
\checkmark \text { Recife } \\
\checkmark \text { Catingueira } \\
\checkmark \text { Goiana } \\
\checkmark \text { Vitória de santo Antão } \\
\checkmark \text { Condado }\end{array}$ \\
\hline $\begin{array}{l}\text { Neuropsychomotor development in children with } \\
\text { microencephaly }\end{array}$ & 9 & $\begin{array}{l}\checkmark \text { Ipojuca } \\
\checkmark \text { Goiana } \\
\checkmark \text { Recife } \\
\end{array}$ \\
\hline $\begin{array}{l}\text { Communicative aspects in children with } \\
\text { microencephaly }\end{array}$ & 14 & $\begin{array}{l}\checkmark \text { Recife } \\
\checkmark \text { Cupira } \\
\checkmark \text { Olinda } \\
\checkmark \text { Lajedo }\end{array}$ \\
\hline Feeding and nutrition of children with microencephaly & 16 & $\begin{array}{l}\checkmark \text { Recife } \\
\checkmark \text { Paulista }\end{array}$ \\
\hline $\begin{array}{l}\text { Advice for maintenance of oral health in children with } \\
\text { microencephaly }\end{array}$ & 7 & $\checkmark$ Recife \\
\hline Fine motor activities in children with microencephaly & 20 & $\begin{array}{c}\checkmark \text { Recife } \\
\checkmark \text { Lajedo } \\
\checkmark \text { Abreu e Lima } \\
\checkmark \text { Floresta }\end{array}$ \\
\hline $\begin{array}{l}\text { Social protection for children diagnosed with } \\
\text { microencephaly }\end{array}$ & 18 & $\begin{array}{c}\checkmark \checkmark \text { Olinda } \\
\checkmark \text { Abreu e Lima } \\
\checkmark \text { Tianguá }\end{array}$ \\
\hline
\end{tabular}

Figure 2. Summary of sessions developed, number of accesses and list of municipalities from which accesses were made

The overall number of viewings and evaluations in the reference period of the study was satisfactory (total: 175 viewings; mean: 25 per action), despite the small number of educational sessions offered (seven). Among the municipalities, Recife had the greatest participation in practically all sessions, followed by Goiana.

Regarding the degree of satisfaction among the participants, $100 \%$ considered the topics interesting and all reported that the learning experience made an important contribution to their professional qualification. Moreover, the vast majority (86\%) reported feeling secure with regards to retaining the information acquired (Table 1).

The results demonstrated the engagement of the health professionals in the context of novel situations, such as actions directed at the repercussions of the triple epidemics. It was also possible to infer that the participants considered the knowledge mediated by information technology satisfactory. Thus, considering the acceptance of the public of this new learning context, the experience can be expanded to include other topics of interest to health professionals who work in primary care. 
Table 1. Summary of evaluation of satisfaction by participants

\begin{tabular}{|c|c|c|c|c|c|c|c|c|c|c|c|c|}
\hline \multirow{2}{*}{ Title of action } & \multicolumn{3}{|c|}{ Interesting topic } & \multicolumn{3}{|c|}{ Quality of content presented } & \multicolumn{3}{|c|}{ Importance of learning to profession } & \multicolumn{3}{|c|}{$\begin{array}{l}\text { Feel secure in retaining } \\
\text { information acquired }\end{array}$} \\
\hline & Yes & No & $\begin{array}{l}\text { I don't } \\
\text { know }\end{array}$ & Good & Poor & $\begin{array}{l}\text { I don't } \\
\text { know }\end{array}$ & Important & $\begin{array}{c}\text { Not } \\
\text { important }\end{array}$ & $\begin{array}{l}\text { I don't } \\
\text { know }\end{array}$ & Yes & No & $\begin{array}{l}\text { I don't } \\
\text { know }\end{array}$ \\
\hline $\begin{array}{l}\text { Current Panorama of the } \\
\text { Triple Epidemics (Zika, } \\
\text { Chikungunya and Dengue) } \\
\text { in Brazil }\end{array}$ & 91 & - & - & 91 & - & - & 91 & - & - & 91 & 6 & - \\
\hline $\begin{array}{l}\text { Neuropsychomotor } \\
\text { development in children } \\
\text { with microencephaly }\end{array}$ & 9 & - & - & 9 & - & - & 9 & - & - & 9 & 2 & - \\
\hline $\begin{array}{l}\text { Communicative } \\
\text { aspects in children with } \\
\text { microencephaly }\end{array}$ & 14 & - & - & 14 & - & - & 14 & - & - & 14 & 7 & - \\
\hline $\begin{array}{l}\text { Feeding and nutrition } \\
\text { of children with } \\
\text { microencephaly }\end{array}$ & 16 & - & - & 16 & - & - & 16 & - & - & 16 & 3 & - \\
\hline $\begin{array}{l}\text { Advice for maintenance of } \\
\text { oral health in children with } \\
\text { microencephaly }\end{array}$ & 7 & - & - & 7 & - & - & 7 & - & - & 7 & 3 & - \\
\hline $\begin{array}{l}\text { Fine motor activities } \\
\text { in children with } \\
\text { microencephaly }\end{array}$ & 20 & - & - & 20 & - & - & 20 & - & - & 20 & 3 & - \\
\hline $\begin{array}{l}\text { Social protection for } \\
\text { children diagnosed with } \\
\text { microencephaly }\end{array}$ & 18 & - & - & 18 & - & - & 18 & - & - & 18 & 1 & - \\
\hline Total & 175 & - & - & 175 & - & - & & - & - & 150 & 25 & - \\
\hline
\end{tabular}

\section{DISCUSSION}

This report describes the experience of a continuing education process for health professionals in primary care involving information and communication technologies to address the repercussions of the Zika virus in the state of Pernambuco, Brazil.

The planning and organization of the work phases are fundamental elements in the implantation of projects, programs and services, ensuring the fulfillment of all goals established in the conception phase. The creation and incorporation of schematic and graphic representations, such as a flowchart, enable the clear, precise description of actions, analysis and the redefinition of procedures to facilitate the understanding of all steps necessary to the structuring of the project. These representations also assist in standardizing the methods and administrative procedures necessary for the implementation of the project, which leads to better management of the entire process ${ }^{19,20}$.

Although consolidated in some regions of Brazil, telehealth needs to be strengthened. Particularly in the state of Pernambuco, despite contributing to the fulfillment of the principles and guidelines of the Brazilian public healthcare system, the use of the services offered remains insufficient ${ }^{21}$, which contributed to the low participation of health professionals in municipalities located in the interior of the state. Indeed, we expected a greater number of viewings and evaluations by health professionals who compose the target public of the action, as the project addressed a topic of considerable concern for the entire country ${ }^{22-24}$.

Recent studies involving telehealth report that one of the major challenges is achieving the engagement of health teams due to the low affinity with the technologies involved, connectivity difficulties or the non-incorporation of this practice in the work routine ${ }^{25-27}$. Thus, there is a need to expand the offer of telehealth services in the state of Pernambuco and Brazil as a whole, as this educational modality enables the promotion of comprehensive care in the most remote locations, thereby strengthening the public healthcare system ${ }^{18,28,29}$.

Satisfaction with the experience was high and all participants reported that the sessions contributed to their work processes. However, we believe that the action should have been able to attract the participation of a greater number of health professionals. With regards to speech therapy and the health of human communication, Nascimento et al. (2017) ${ }^{27}$ state the tele-health, which is an only recently regulated practice, needs to be more widely disseminated. The efforts of speech therapists regarding the use of telehealth services and the expansion of publications on this issue 
could help strengthen lines of care in human communication health.

The present results lend support to the premise that continuing education sessions indeed contribute to the action-reflection-action process as well as the qualification of health professionals and the organization of work processes. This initiative, coupled with other technologies and processes, such as telehealth, tends to propagate more effectively, assisting health professionals in responding quickly to situations that require greater agility in decision-making processes ${ }^{28,29}$.

Studies addressing the contribution of teleeducation report that this service is an important option for continuing education, enabling health professionals to engage in reflective, theoretical discussions based on the needs of the local population ${ }^{18,26,30,31}$.

The present results may have been influenced by the topic addressed, which is a concern throughout out the entire country, requiring health professionals to invest more in the acquisition of knowledge on intervention and rehabilitation measures ${ }^{22,24}$.

The proposal described in this report could contribute to the development of new models regarding the health of human communication and emergency care situations, such as the repercussions of Zika virus. It could also make a contribution to other fields of health with the aim of strengthening continuing education processes in primary care. Moreover, the dissemination of this implantation project could broaden the scope of educational sessions in primary care directed not only at the specific epidemiological components of the Zika virus but also all aspects of communication disorders.

The major limitation of the present study was the small number of evaluations, which restricted the analysis of the contribution of tele-education. Greater dissemination of the Brazilian Telehealth Program throughout the entire country could assist in a more complete evaluation of the comprehensiveness of the project with regards to strengthening the public healthcare system.

\section{CONCLUSIONS}

The implementation of the tele-education service had repercussions on statewide views and was approved by $100 \%$ of the participants. This is a promising, easily accessible, comprehensive proposal for the continued education of health professionals working in primary care and at Family Health Support Centers.

\section{REFERENCES}

1. Caveião C. Vírus Zika suas complicações relacionadas à microcefalia e Guillain-Barré. Saúde. 2016;1(15):3-6.

2. Secretaria Executiva de Vigilância em Saúde. Informe Técnico - no 03/2019. Síndrome congênita relacionada à infecção pelo vírus Zika. [cited 2019 Jun05]. Disponível em: https://docs.wixstatic.com/ ugd/3293a8_070a403ca151417e91d5e98ddc 6526a8.pdf.

3. Martinez-Pulgarin DF, Acevedo-Mendoza WF, Cardona-Ospina JÁ, Rodriguez-Morales AJ, PanizMondolfi AE. A bibliometric analysis of global Zika research. Travel Medicine and Infectious Disease. 2016;14(1):55-7.

4. Galavote HS, Franco TB, Freitas PSS, Lima EFA, Garcia ACP, Andrade MAC et al. A gestão do trabalho na estratégia saúde da família:(des) potencialidades no cotidiano do trabalho em saúde. Saúde e Sociedade. 2016;25(4):988-1002.

5. Ferreira AF, Cortez EA, Fernandes ACM, Almeida LP. A educação permanente em saúde como contribuição para o registro de enfermagem. Revista Online de Pesquisa. 2018;10(3):92-5.

6. Cavalcanti FOL, Guizardi FL. Educação continuada ou permanente em saúde? Análise da produção pan-americana da saúde. Trabalho, Educação e Saúde. 2018;16(1):99-122.

7. Queiroz GS, Santos MLR. A mediação da aprendizagem na educação permanente em saúde: análise da sua capacidade de problematizar. Revista EDaPECI. 2018;18(2):24-36.

8. Bevilacqua $P$, Melo $C M$, Barletto $M$. Educação Permanente em Vigilância em Saúde: formação política e reorientação de práticas em serviços. In: Ferla AA, Pinto HÁ (orgs). Integração entre universidade e sistemas locais de saúde: experimentações e memórias da educação pelo trabalho. Porto Alegre: Rede UNIDA; 2017. p. 78-102.

9. Vieira RR, Corvino M, Almeida ACV, Mourão LC. Reflexões multidisciplinares em serviço e sua influência na prática do médico da atenção básica: contribuições da educação permanente em saúde. Revista Pró-Univer SUS. 2018;8(2):128-9.

10. Wen CL. Telemedicina - visão sob foco de uma disciplina. Rev Telem Telessaude. 2006;2(2):20-8.

11. Wen CL. Telemedicina e telessaúde - um panorama no Brasil. Informática Pública. 2008;10(2):7-15. 
12. Spinardi ACP, Quinhoneiro BW, Lung WC, Paula LM. Telefonoaudiologia: ciência e tecnologia em saúde. Pró-fono R. Atual. Cientif. 2009;21 (3):249-54.

13. Bones AANS, Costa MR, Cazella SC. A educação para o enfrentamento da epidemia do HIV. Interface. 2018;22(1):1457-69.

14. Garcia LP. Epidemia do vírus Zika e microcefalia no Brasil: emergência, evolução e enfrentamento, Texto para Discussão, No. 2368, Instituto de Pesquisa Econômica Aplicada (IPEA), Brasília; 2018. p.1-53.

15. Ferretti F, Romancini F, Schneider LR, Ferraz L. Prática baseada em evidência no contexto dos núcleos de apoio a saúde da família em Chapecó. Cogitare Enferm. 2018;23(2):e52774.

16. Brasil. Ministério da saúde. Gabinete do Ministro; Portaria $n^{\circ}$ 2.546, de 27 de outubro de 2011. Redefine e amplia o Programa Telessaúde Brasil, que passa a ser denominado Programa Nacional Telessaúde Brasil Redes (Telessaúde Brasil Redes). Diário Oficial da União. 2011. [Accessed on 25 August 2016]. Available from: http:// bvsms.saude.gov.br/bvs/saudelegis/gm/2011/ prt2546_27_10_2011.html.

17. Conselho Federal de Fonoaudiologia. Resolução n. 427 , de 1 o de março de 2013. Dispõe sobre a regulamentação da Telessaúde em Fonoaudiologia e dá outras providências. Diário Oficial da União. 05 mar 2013; Seção 1:158. [Accessed on 25 August 2016]. Available from: http://www.fonoaudiologia. org.br/legislacaoPDF/Res\%20427-2013.pdf.

18. Leitão GGS, Silva TPSS, Lima MLLT, Rodrigues M, Nascimento CBM. Educational actions in human communication health: telehealth contributions in primary care. Rev. CEFAC. 2018;20(2):182-90.

19. Nascimento VF. Fluxograma de acesso e atendimento de Enfermagem em Unidade de Saúde Da Família. Revista Eletrônica Gestão \& Saúde. 2013;4(1):1922-27.

20. Tabile PM, Berbhard TW, Müller E, Dihel D, Koepp J. A importância do fluxograma para o trabalho da saúde da família na visão do projeto PET-saúde. Revista Eletrônica Gestão \& Saúde. 2015;6(1):680-90.

21. Novaes MA Machiavelli JL, Verde FCV, Campos Filho AS, Rodrigues TRC. Tele-educação para educação continuada das equipes de saúde da família em saúde mental: a experiência de Pernambuco, Brasil. Interface-Comunicação, Saúde, Educação. 2012;16(43)1095-106.
22. Petrônio CNV, Melo AMD, Neto EM, Sampaio JAA, Telles MVL, Souza CMSC. O Início da epidemia do Zika Vírus e os seus reflexos na Saúde Pública Nacional e Internacional. Id online Revista de Psicologia. 2018;12(40):1232-35.

23. França LS, Macedo MA, Vieira SNS, Santos AT, Sanches GJC, Silva JM et al. Challenges for the control and prevention of the aedes aegypti mosquito. Journal of Nursing UFPE. 2017;11(12):4913-8.

24. Williamson EK. Cuidado nos tempos de Zika: notas da pós-epidemia em Salvador (Bahia), Brasil. Interface-Comunicação, Saúde, Educação. 2018;22(66):685-96.

25. Figueiredo VCJ, Corrêa CRS. A implantação do Telessaúde em Campinas. Trabalhos Completos ALED BRASIL. 2016;2(4):1-14.

26. Oliveira DG, Frias PG, Vanderlei LCM, Vidal AS, Novaes MA, Souza WV. Análise da implantação do Programa Telessaúde Brasil em Pernambuco, Brasil: estudo de casos. Cadernos de Saúde Pública. 2015;31(11):2379-89.

27. Nascimento CMB, Lima MLLT, Sousa FOS, Novaes MA, Gldino DR, Silva ECH et al. Telespeech therapy as a continued education strategy in primary health care in the state of Pernambuco, Brazil. Rev. CEFAC. 2017;19(3):371-80.

28. Dantas RM, Santos IT, Araújo JC, Neto NB. A Telessaúde como instrumento de educação em saúde: uma revisão da literatura. Saúde. com. 2016;12(4):688-92.

29. Fiorentino G, Sebastião B, Mattos L, Grass K. Tendências do setor de saúde no Brasil. Bain \& Company, São Paulo; 2016.

30. Bernardes LM. Análise da tele-educação interativa em tuberculose no Município de Praia Grande [tese]. Santos (SP): Universidade Católica de Santos, Curso de Saúde Coletiva, Departamento de Ciências Sociais Aplicadas a Saúde; 2016.

31. Maeyama MA, Calvo MCM. The integration of telehealth in regulation centrals: the teleconsulting as a mediator between primary care and specialized care. Revista Brasileira de Educação Médica. 2018;42(2):63-72. 